showing the effect of temperature of processing on the enzyme activity of pears and plums. Some varieties of both fruits have an oxidase enzyme system which is still active at temperatures which had been recommended for bottling as sufficient to prevent spoilage by micro-organisms. The result is that the uppermost fruits, in the headspace of the jar, become brown and this discoloration spreads over the rest of the fruit if left partly uncovered for any length of time after opening.

An investigation of the enzyme activity in these fruits shows that it varies considerably in the different varieties and stage of ripeness of the fruit. Higher temperatures or longer times of processing are being worked out to prevent serious discoloration without over-cooking.

R. W. MaRSH

\section{MIXING AND AGITATING}

ATHOUGH agitation constitutes one of the A basic or unit operations of chemical engineering and finds application, in one form or another, in nearly every major industry, very little is yet known about its mechanism or about the efficiencies to be expected from well-designed industrial stirring equipment.

A conference on "Mixing and Agitating in Liquid Media", arranged by the Institution of Chemical Engineers and held at the Royal Institution on July 17, was opened by Sir Harold Hartley, president of the Institution of Chemical Engineers. Sir Harold emphasized the need for more research and practical data on the hydrodynamics of systems in turbulent motion ; and he referred in particular to the factors governing the operation and efficiency of processes such as that of the catalytic hydrogenation of fats, in which the three-phase interface required for rapid reaction has to be produced by agitation.

The introductory paper to the conference was given by Prof. D. M. Newitt, G. C. Shipp and C. R. Black, and reviewed briefly recent theoretical developments relating to the conditions which must be imposed upon heterogeneous systems to give rise to, and maintain, dynamic uniformity. The extent to which existing equipment reproduces the 'ideal' flow pattern for rapid and complete mixing was discussed by B. N. Reavell, who showed how a knowledge of the flow properties and viscosities of suspensions can be made to serve as a basis for classifying the wide variety of mixing problems encountered by the chemical engineer.

The importance of the application of hydraulics and hydrodynamics to the study of mixing was referred to by several speakers. Describing the mixing action of free jets, H. Fossett advocated the use of models to enable the hydraulic criteria govern. ing their action to be established. From a rather different point of view, Prof. F. H. Garner and A. H. P. Skelland illustrated, by a ciné-film, the conditions under which internal circulation can be produced in droplets of a dispersed liquid phase; their experiments lead to the conclusion that the surface viscosity of the fluid in the droplet is probably a major factor in determining the onset of circulation.

The more practical aspects of the subject were dealt with in two papers devoted to the special problems of the fuel and ceramic industries. R. A. A. Taylor, of the Fuel Research Station, described the processes by which coal is suspended in, or incorporatediwith, water, oil, tar and other liquids, while
F. J. Goodson and Dr. A. E. Dodd discussed the manufacture of earthenware bodies by a method in which the ingredients-china clay, ball clay, calcined flint and Cornish stone, disintegrated and dispersed in water-have to be mixed in the correct proportions and as uniformly as possible In both papers the operational and economic factors governing the choice of equipment were stressed.

Among the visitors taking part in the discussion were Mr. Thomas Chilton, president of the American Institute of Chemical Engineers, and Prof. H. A. Kramers, of the University of Delft.

\author{
D. M. NEwITT
}

\section{ORIGIN AND IMPROVEMENT OF CULTIVATED PLANTS}

A

USEFUL review by M. B. Crane of past and present methods used in crop improvement forms the text of the Masters Memorial Lectures of the Royal Horticultural Society for 1950 ( J.Roy. Hort. Soc., 75, Parts 11 and 12; November and December 1950). Most of the crops of gardens and farms in Great Britain have attained their present economic desirability either as gene-mutations, through autopolyploidy, or by selection of interspecific hybrids with or without chromosome doubling. The sweet pea, Chinese primula, tomato, raspberry and edible pea are examples of improvement by gene-mutations.

Periclinal chimæras combined with gene-mutations have given certain economically acceptable plants. The potato variety Golden Wonder is a periclinal gene-mutation of the older Langworthy, differing only in its skin. Raspberries, pears, apples, tulips, hyacinths and narcissi are examples of plant improvement by autopolyploidy; chromosome numbers of the 'wild' form have been trebled or quadrupled in the cultivated variant. The strawberry provides an example of interspecific hybridization between the species Fragaria vesca, $F$. elatior, $F$. virginiana and $F$. chiloensis. Plurs have arisen as interspecific hybrids between Prunis cerasifera and $P$. spinosa; but here the hybrid has been subject to polyploidy.

Mr. Crane dealt in his second lecture with the use and extension of these methods in practice. Polyploidy can be induced by treatment with the drug colchicine, by heat shock of plant shoots at $45^{\circ} \mathrm{C}$. for one or two hours, by decapitation, and by exposure to $X$-rays. The action and interaction of genes is now studied very intensively, though the effect is to reveal a complexity far more bewildering than the original Mendelian ratio. This knowledge is put to practical use, however, in such problems as that of raising the vitamin $A$ content of maize. The gene affecting this is related with endosperm colour. Octaploid organization of the dahlia makes possible the fascinating variations of the flower; the expres. sion of dominance is more variable than in diploid plants. Vegetative propagation is a method of perpetuating hybrid vigour, and this fact could be used more consciously by plant improvers. Several examples were given of breeding for resistance to fungal diseases and insect pests. This problem is, however, complicated by the occurrence of strains in the disease-producing fungi, but several examples of valuable degrees of resistance are now known. They contribute significantly to the economy and food of nations. 